\title{
Cladonia subturgida (Cladoniaceae, Lecanoromycetes), an overlooked, but common species in the Mediterranean region
}

\author{
Raquel Pino-Bodas ${ }^{1}$ (D) - Elena Araujo ${ }^{2}$ - Blanca Gutiérrez-Larruga ${ }^{2} \cdot$ Ana Rosa Burgaz $^{2}$
}

Received: 13 April 2020 / Accepted: 25 May 2020 / Published online: 8 June 2020

(C) The Author(s) 2020

\begin{abstract}
Cladonia subturgida is a Mediterranean species that has been overlooked. Apparently it was restricted to the Iberian Peninsula and Canary Islands. However, during the study of the genus Cladonia in the Mediterranean region, new populations from 44 localities were found in: south France, Sardinia, south Italian peninsula, Crete and continental Greece. Distribution models based on MaxEnt, GLM, GAM and MARS algorithms were used to estimate the potential distribution of C. subturgida. Sicily, Corsica and the north of Africa were regions with suitable climatic conditions for $C$. subturgida where it has not been reported yet. The climatic variables with greatest relative influence in the C. subturgida distribution were the Precipitation of Warmest Quarter and the Annual Precipitation. Additionally, the ITS rDNA region was used to study the genetic variation of this species across its distribution area. Eleven haplotypes were found, one of them widely distributed through its geographical range. AMOVA analyses indicated lack of geographical structure.
\end{abstract}

Keywords Cladoniaceae $\cdot$ Distribution modelling $\cdot$ Genetic diversity $\cdot$ Lichen forming fungi

\section{Introduction}

The Mediterranean basin is one of the world's biodiversity hotspots (Médail and Quézel 1999; Myers et al. 2000), concentrating $10 \%$ of all the known vascular plants, of which $80 \%$ are endemic (Fady-Welterlen 2005). Three factors are crucial to explain the high biodiversity of the Mediterranean basin: the complicated geology of the area, the climate, characterized by hot and dry summers, and the high impact of human activities, that have substantially altered the landscape (Thompson 2005).

There exist lichen catalogues for several Mediterranean countries (e.g. Litterski and Mayrhofer 1998; Llimona and Hladún 2001; Abbott 2009; Mayrhofer et al. 2013; Roux 2012; Nimis 2016). According to these inventories, more than 2500 lichen species grow in this region, though its diversity is

Electronic supplementary material The online version of this article (https://doi.org/10.1007/s13199-020-00688-7) contains supplementary material, which is available to authorized users.

Raquel Pino-Bodas

r.pino@kew.org

Royal Botanic Gardens, Kew, Richmond, Surrey TW9 3DS, UK

2 Department of Biodiversity, Ecology and Evolution, Complutense University, E-28040 Madrid, Spain not absolutely well-known, since many areas are still poorly explored, especially in North Africa. For reasons of similarity to the Mediterranean biogeographical pattern of vascular plants (Thompson 2005), several authors have adopted this same pattern in lichens (Nimis and Poelt 1987; Nimis and Tretiach 1995; Galloway 2008). Yet the validity of this assumption has been questioned because very few endemic lichen species exist in the Mediterranean region (Barreno 1991; Nimis 1996; Nimis 2016), unlike what happens with plants.

The lichens of the genus Cladonia are characterized by a dimorphic thallus composed by a crustose or foliose primary thallus and a fruticose secondary thallus. In the Mediterranean region, the species of this genus mainly grow on roadside slopes, shrublands (as heaths), and pine groves (Burgaz and Ahti 2009), since most of the species are heliophilous. Though the genus Cladonia has been well studied in some countries of the Mediterranean basin, such as Spain, Croatia, Italy, France, Georgia (Burgaz and Ahti 2009; Nimis 2016; Burgaz and Pino-Bodas 2012; Burgaz et al. 2017; Roux 2017), the current knowledge for the whole region is still scarce, and the proof is that new records are regularly reported (Burgaz et al. 2017, 2019a, 2019b; Monia et al. 2018; Gheza et al. 2018; Kocakaya et al. 2018). To date, 90 species of this genus have been reported for the Mediterranean basin (Burgaz et al. 2020). The species of Cladonia present in the region show different distribution patterns; many of them have wide distributions that 
embrace several continents (e.g., C. furcata, C. humilis, C. pyxidata, etc.), while others are restricted to Europe and Macaronesia (for instance C. subcervicornis, C. cyathomorpha). Some species of Cladonia characteristic of the Mediterranean region are, for example, C. mediterranea, C. cervicornis, C. subturgida, C. foliacea, C. rangiformis and C. firma (Litterski and Ahti 2004; Burgaz and Ahti 2009; Ahti and Stenroos 2013). Though these species do not restrict themselves to the Mediterranean region, it is there where they are most abundant (Litterski and Ahti 2004; Burgaz and Ahti 2009; Ahti and Stenroos 2013).

Cladonia subturgida is a species with a persistent and dominant primary thallus, often lacking a secondary thallus (Fig. 1a, b). It is distributed in the western area of the Iberian Peninsula and in the Canary Islands (Pino-Bodas et al. 2012). During our field work in different countries of the Mediterranean region (France, Italy, Greece) we found numerous specimens of $C$. subturgida. We hypothesize that
C. subturgida is a common species in the Mediterranean region, but poorly sampled, or mistaken for other species of Cladonia with dominant primary thallus, such as $C$. cervicornis and C. firma. In order to test this hypothesis, species distribution models have been used, based on all the known records. Species distribution models are helpful when it comes to understanding the environmental factors that determine the occurrence of species. These methods have been succesfully used to predict the potential distribution of several epiphytic lichen species (Glavich et al. 2005; Bolliger et al. 2007; Pearson et al. 2018; Guttová et al. 2019), and likewise to assess the impact of the climatic change on the lichen distribution, to propose conservation plans (Allen and Lendemer 2016; Ellis et al. 2007; Wiersma and Skinner 2011; Pearson et al. 2018; Ellis 2019), and to determine zones that played the role of glacial shelters for certain species (Kukwa and Kolanowska 2016).

In this study we report new findings of Cladonia subturgida in several countries of the Mediterranean basin,

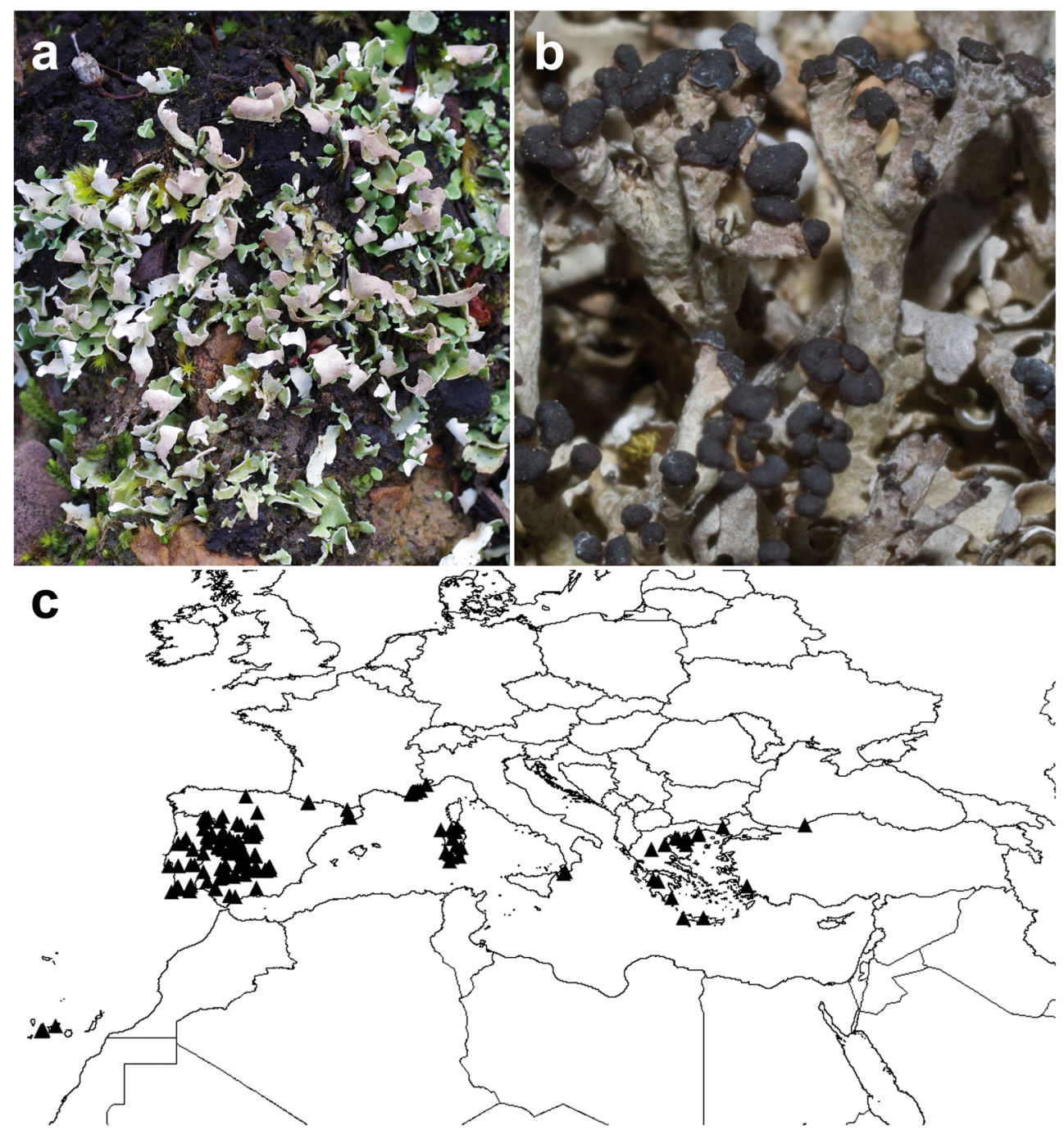

Fig. 1 a Primary thallus of Cladonia subturgida $\mathbf{b}$ Podetia of $C$. subturgida $\mathbf{c}$ Distribution of $C$. subturgida based on specimens studied and literature references 
the chemical variation of this species and its genetic diversity based on ITS rDNA region. Additionally, we model its potential distribution in order to identify the key environmental variable that shapes the ecological niche of $C$. subturgida.

\section{Material and methods}

\subsection{Specimens studied}

Specimens were collected from France, Italy, Sardinia, Greece and Crete between 2015 and 2018 (Supplementary material). The surveys were conducted on ca. 260 localities. All the new collections were deposited at MACB herbarium in Madrid and some duplicates were sent to Helsinki $(\mathrm{H})$ and Trieste (TSB) herbaria. The secondary metabolites of each specimen were analysed by thin layer chromatography (TLC) according to standardized procedures (White and James 1985; Orange et al. 2001), using the solvents A, B and C.

Thirty eight newly collected specimens, in addition to the sequences from Pino-Bodas et al. (2012), were used to estimate the genetic diversity of $C$. subturgida. The specimens selected covered the whole distribution area (Fig. 1c). In total we included 18 specimens from Greece, three from Southern Italy, seven from Sardinia, nine from Spain, ten from France, one from Portugal and one from Canary Islands. The ITS rDNA region, the barcoding of fungi (Schoch et al. 2012), was selected to study the genetic diversity of Cladonia subturgida.

\subsection{DNA extraction and amplification}

The E.Z.N.A. Forensic DNA Isolation Kit (Omega Bio-Tek) was used to extract the genomic DNA, following the manufacturer's instructions. PCRs were carried out with Biotaq polymerase (Bioline). The volume of reaction was $25 \mu \mathrm{l}$, $0.3 \mu \mathrm{L}$ of $\mathrm{Taq}$ polymerase, $2.5 \mu \mathrm{L}$ of $10 \times$ PCR buffer, $1.4 \mu \mathrm{L}$ of $\mathrm{MgCl} 250 \mu \mathrm{m} / \mu \mathrm{L}, 1.6 \mu \mathrm{L}$ of dNTPs $(2.5 \mu \mathrm{m} /$ $\mu \mathrm{L}), 1 \mu \mathrm{L}$ of BSA $(1 \mu \mathrm{m} / \mu \mathrm{L}), 1 \mu \mathrm{L}$ of each primer $(10 \mu \mathrm{m} /$ $\mu \mathrm{L}$ ), and $1 \mu \mathrm{L}$ of extracted DNA. The primers used to amplify ITS rDNA region were ITS1F and ITS4 (White et al. 1990; Gardes and Bruns 1993) and PCR program was initial denaturation at $95^{\circ} \mathrm{C}$ for $2 \mathrm{~min}$; five cycles of $95^{\circ} \mathrm{C}$ for $30 \mathrm{~s}, 58^{\circ} \mathrm{C}$ for $30 \mathrm{~s}$ and $72{ }^{\circ} \mathrm{C}$ for $1 \mathrm{~min}$ and 34 cycles of $95^{\circ} \mathrm{C}$ for $30 \mathrm{~s}$, $56^{\circ} \mathrm{C}$ for $30 \mathrm{~s}$ and $72{ }^{\circ} \mathrm{C}$ for $1 \mathrm{~min}$; with a final extension at $72{ }^{\circ} \mathrm{C}$ for $10 \mathrm{~min}$. PCR products were cleaned with ExoProStar TM 1-step (GE Healthcare). The sequencing reactions were done at Macrogen Spain service (www. macrogen.com), with the same primers used for the PCR.

Sequencher 4.1.4 program (Gene Codes Corporation, Inc., Ann Arbor, Michigan, USA) was used to assemble the sequences. The alignment was made in MAFFT (Katoh and Standley 2013), then it was checked and improved manually in
BIOEDIT 7.0 (Hall 1999). A phylogenetic analysis based on ITS rDNA was carried out to test the monophyly of Cladonia subturgida. One hundred and sixty one species of Cladonia were included in this analysis based on the phylogenetic study of Stenroos et al. (2019). Cladonia wainioi was selected as outgroup. The ambiguous regions were removed using Gblock (Talavera and Castresana 2007) with the less stringent options. The alignment contained 211 sequences and 524 positions. Maximun likelihood analysis was implemented in RAxML 7.0.3 (Stamatakis et al. 2005) assuming the GTRGAMMA model. The bootstrap searches were conducted with 1000 pseudoreplicates using the rapid bootstrap algorithm.

\subsection{Genetic diversity and haplotype analyses}

The program DnaSP (Librado and Rozas 2009) was used to calculate the haplotype diversity, segregate sites and nucleotide diversity. Haplotype network under statistical parsimony were constructed in TCS 1.21 (Clement et al. 2000), considering the gaps as missing data. Mantel test was carried out to study the correlation between the ITS rDNA genetic distances and the geographical distances (using Euclidean distance) with 2000 random permutations to test the significance in VEGAN package (Oksanen et al. 2007) for R.

Analysis of molecular variance (AMOVA) was performed in Arlequin v 3.5 (Excoffier and Lischer 2000) in order to assess the proportion of the genetic variation attributed to different geographical regions (Iberian Peninsula, France, Italy and Greece). The single specimen from Canary Islands was excluded from these analyses.

\subsection{Species distribution modeling}

Species distribution modeling was used to estimate the potential distribution of $C$. subturgida under the current climatic conditions. The distribution modeling was based on 158 occurrence records whose identification has been verified by morphological studies according to Pino-Bodas et al. (2012) under dissecting microscope. The 19 bioclimatic variables at 2.5 min of spatial resolution were downloaded from the WorldClim website (https://www.worldclim.org; Hijmans et al. 2005). A pseudo-absences set was generated avoiding the overlap with the presences. Firstly the models were generated using all bioclimatic variables. Then, the models were estimated using only uncorrelated variables, according Kendall rank correlation coefficient, and selecting those variables which contributed more significantly in the first models. The variables selected were: Annual Mean Temperature (BIO1), Temperature Seasonality (BIO4), Mean Temperature of Driest Quarter (BIO9), Mean Temperature of Coldest Quarter (BIO11), Annual Precipitation (BIO12) and Precipitation of Warmest Quarter (BIO18). 
Four modeling methods were used: Generalized additive models (GAM), generalized linear models (GLMs), Multivariate adaptive regression splines (MARS) and maximum entropy (Maxent). The models GAM, GLMs and MARS were implemented in R using the libraries GAM, DISMO and EARTH (Wood 2012; Milborrow et al. 2014; Hijmans et al. 2017). The method selected to assess the model fitting was the area under the receiver operating characteristic curve (AUC) (Fielding and Bell 1997). This value gives a measure of model discrimination accuracy, values close to 1 indicate a good discrimination. Jackknife test was run in Maxent, using 25 random points and 5 replicates to estimate the contribution of each variable to the model. This test compares the fitting of the models with and without a variable in order to assess the contribution of this variable to the distributionl prediction (Phillips et al. 2006).

Then a consensus ensemble prediction from all individual models with selected variables was built.

\section{Results}

In this study 44 new records of Cladonia subturgida for three countries are presented. The specimens were collected in south France, Sardinia, south continental Italy, Crete and continental areas of Greece, representing the first records for all the countries. The complete distribution of $C$. subturgida is presented in Fig. 1c, based on the new data, our previous studies (Burgaz and Ahti 2009; Pino-Bodas et al. 2012) and a few literature reports (Kocakaya et al. 2018). It grows on bare soils or earth banks, preferably acidic or subneutrophilous soils of xerothermic evergreen vegetation dominated by Cistus shrubs, heathlands, Pinus or Quercus woodlands, in an altitude range from 25 to $1760 \mathrm{~m}$.

Twelve populations were found in France at the ProvenceAlpes-Côte d'Azur Region. Eleven from the Department of Var (Le Cannet des Maures, Massif des Maures and Massif de l'Esterel) and one from Alpes-Maritimes (Contes). The species was found on acidic substrate of Quercus suber, Pinus pinea and $P$. pinaster forests, 33-476 $\mathrm{m}$ altitude. In Italy 17 populations were found, 15 of them from Sardinia, growing on maquis shrubland with Quercus suber or deciduous Quercus and acidic substrate. Additionally, two populations were found in Calabria, on Cistus monspeliensis shrubs and deciduous Quercus, growing between 459 and $607 \mathrm{~m}$ altitude. Fifteen populations were found in Greece. Eight of them in Macedonia and Thrace, one in Thessaly, three in the Peloponnese, and one in West-Greece counties, growing on Quercus coccifera and Pistacia lentiscus formations, on acidic soils. In Crete island two populations were found, one of them in Heraklion and the another one in Chania, growing on Arbutus unedo and Erica manipuliflora shrubs.
The accompanying species were Cladonia cervicornis, C. corsicana, C. firma, C. foliacea, C. humilis, C. pyxidata or $C$. ramulosa.

Table 1 shows the chemical variation found in the new collections of $C$. subturgida. Eight different chemotypes were detected, the most common contains atranorin and protolichesterinic acid and the second one contains additionally zeorin. Greek populations were the most variable chemically, with seven different chemotypes. Five of them were present in Crete (Table 1). Intra-population chemical variation was detected on tree localities, all of them from Greece. In one locality in the Peloponnese the chemotypes I and III were detected, in one locality in Macedonia-Thrace the chemotypes I and IV were detected and in Chania, Crete Island, the chemopytes I, III and VII were found.

The new DNA sequences generated have been deposited in GenBank (MT510881-MT510918). The phylogenetic analysis shows that $C$. subturgida is monophyletic (Fig. 1S). A single haplotype network containing 11 haplotype without missing haplotypes was generated by TCS. One haplotype was widespread in the Mediterranean basin (Fig. 2), three haplotypes were unique to Greece, one was exclusive to south Italy, one was exclusive to France, one was restricted to Sardinia and two were exclusive to Iberian Peninsula. Three haplotypes were shared: one was shared between populations from Spain and France, other haplotype was shared between populations from Spain and Portugal and a third haplotype was shared between populations from Spain and Greece.

The genetic diversity of Cladonia subturgida is presented in Table 2. The populations from the Iberian Peninsula were the most diverse, following those from Greece. The AMOVA test did not show differentiation among the populations of different regions (Table 3). The Mantel test did not find any correlation between the genetic distance of $C$. subturgida and the geographical distance $(\mathrm{r}=0.04239, P$ value $=0.24338)$.

Table 1 Chemical variation of C. subturgida found in the specimen newly collected

\begin{tabular}{lllll}
\hline Chemotypes & France & Greece (Crete) & Italy & Total \\
\hline ATR, PLIC & 3 & $9(1)$ & 16 & 28 \\
ATR, PLIC, ZEO & 6 & 2 & 8 \\
ATR, PLIC, FUM & & $4(1)$ & 4 \\
ATR, PLIC, FUM, ZEO & 2 & 1 & 3 \\
ATR, FUM & 1 & & 1 \\
ATR & & $1(1)$ & 1 \\
FUM & & $1(1)$ & 1 \\
FUM, PLIC & & $1(1)$ & 1 \\
\hline
\end{tabular}

ATR Atranorin, PLIC Protolichesterinic acid, FUM Fumarprotocetraric acid complex, ZEO Zeorin 
Fig. 2 a Geographical distribution of the haplotypes of Cladonia subturgida b Haplotype network inferred by TCS based on ITS rDNA region. Each circle represents a haplotype, the circle size is proportional to haplotype frequency

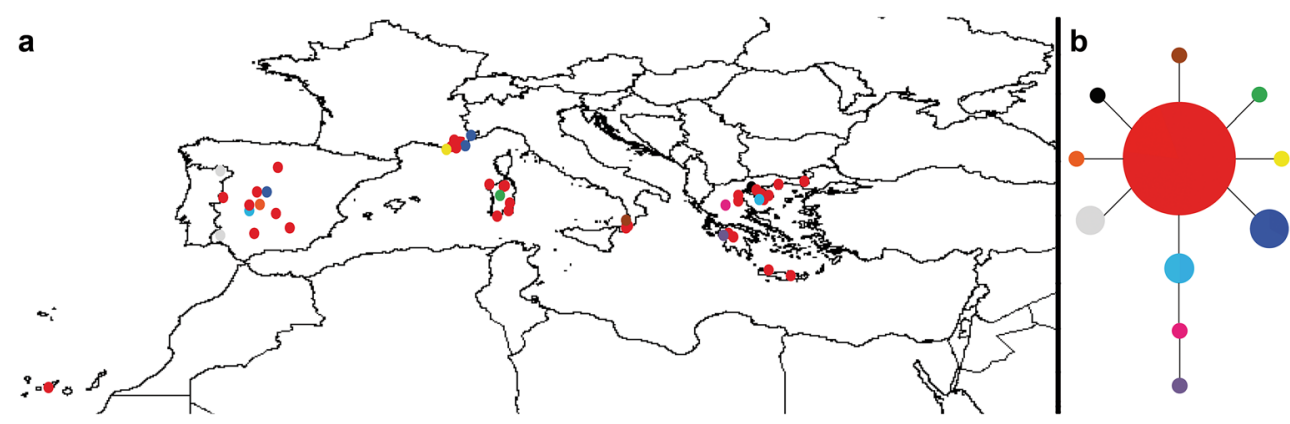

\subsection{Species distribution modelling}

In total, 9 models were generated, 2 for each of the methods used, plus the consensus model of all models with selected variables. The AUC values obtained for each model with selected variables are shown in Table 4. All the models showed high AUC values (>0.90), meaning a fine fitting. The overall agreement among models built using different methods was high (see suplementary material). Table 5 shows the relative contribution of every climatic variable. Annual Precipitation (37.3\%) and Precipitation of Warmest Quarter (25.6\%) were the variables with highest contribution to the models.

Figure 3 shows the consensus model, showing the areas with the highest suitability for $C$. subturgida. The predicted suitable areas for C. subturgida were the Iberian Peninsula, southern France, Corsica, Sardinia, Sicily, Italian Mediterranean area, Greece, western Turkey, north of Africa and a few spots on the southernmost parts of England.

\section{Discussion}

\subsection{New records and distribution of Cladonia subturgida}

This species was described for Portugal (Sampaio 1918) and for a long time known only from the type locality (Burgaz and Ahti 1998, 2009). Morphological similarities with C. iberica were noted (Burgaz and Ahti 1998, 2009)

Table 2 Genetic diversity of Cladonia subturgida across its distribution range

\begin{tabular}{llllll}
\hline & $\mathrm{N}$ & $\mathrm{h}$ & $\mathrm{H}$ & $\pi$ & $\mathrm{S}$ \\
\hline Iberian populations & 12 & 5 & 0.66667 & 0.00143 & 4 \\
French populations & 9 & 3 & 0.55556 & 0.00109 & 2 \\
Italian populations & 10 & 3 & 0.37778 & 0.00071 & 2 \\
Greek populations & 17 & 5 & 0.42647 & 0.00137 & 4 \\
Total & 49 & 11 & 0.54965 & 0.00146 & 10 \\
\hline
\end{tabular}

$N$ number of specimens, $h$ number of haplotypes, $H$ haplotype diversity, $S$ number of polymorphic sites and the phylogenetic studies confirmed that both taxa, C. iberica and C. subturgida, represented a single species phenotypically very variable, distributed in the Iberian Peninsula and Canary Island (Burgaz and Ahti 2009; Pino-Bodas et al. 2012). Recently, it has been reported for Turkey (Kocakaya et al. 2018) and the authors consider that this species should be common in the Mediterranean region, though reported only as scattered. Our results confirm that $C$. subturgida is widely distributed in the Mediterranean basin. The reasons why this species has been scarcely cited could be the following: 1) In general, only the primary thallus is developed; 2) It has been mistaken for other species; 3) Insufficient sampling in the territory. With the exception of some few species, the identifications of Cladonia based on the characters associated with the primary thallus are difficult (Ahti 2000). Although the colour and the morphology of the squamules of $C$. subturgida are very characteristic, the species can be difficult to identify for the non-specialists in the genus since it is morphologically very variable (Pino-Bodas et al. 2012). It is characterized by a dominant primary thallus with large and fragile, (6-25 mm long $\times 1.5-4 \mathrm{~mm}$ wide) undivided and laciniate or deeply lobate (Fig. 1). The upper surface is green glaucous to green olivaceous; lower surface white, purplish toward the margin. Podetia are rare, branched near the tips with open axils and corticate (Pino-Bodas et al. 2012; Burgaz et al. 2020).

In addition, $C$. subturgida is also chemically very variable. Pino-Bodas et al. (2012) reported six different chemotypes, five of which are also present in the newly collected material. In accordance with previous studies the commonest chemotype is the one containing atranorin and protolichesterinic acid. The latter substance is absent from most of the species morphologically closely related. But it is an aliphatic acid that can only be detected by TLC or HPLC methods and in many cases these techniques are not routinely used to identify Cladonia specimens (Haughland et al. 2018). The species morphologically close for which $C$. subturgida could have been mistaken are $C$. firma and $C$. cervicornis, both common in the Mediterranean region and with a dominant primary thallus (Burgaz and Ahti 2009; Pino-Bodas et al. 2012). Although both species have podetia with scyphi and 
Table 3 Analyses of molecular variance (AMOVA) among populations from different geographical areas (Iberian Peninsula, France, Italy and Greece)

\begin{tabular}{lllllll}
\hline & d.f. & S.S & Variance & \% variation & Fst & $P$ value \\
\hline Among populations & 3 & 1.043 & 0.00611 & 2.17915 & 0.02179 & 0.13196 \\
Within populations & 45 & 12.345 & 0.27433 & 97.82085 & & \\
Total & & 13.388 & 0.28044 & & & \\
\hline
\end{tabular}

C. subturgida never has scyphi, thalli without podetia are highly frequent (Burgaz and Ahti 2009).

Our result indicates that more lichen sampling in the Mediterranean region is needed, even in the countries where the lichens have been best studied, like Italy and France. Though terricolous lichens in the Mediterranean region have been studied (for instance Klement 1969; Alonso and Egea 1994, 1995; Martínez et al. 2006; Gheza et al. 2016; Cogoni et al. 2011), in general they are less well known than epiphytic ones (Nimis and Martellos 2004; Nimis 2016).

According to the potential distribution models, the regions with climatic conditions suitable for the growth of C. subturgida, but in which it has not yet been reported, are Sicily, Corsica, north of Africa (including the northern regions of Morocco, Algeria and Tunisia), certain enclaves in Cyprus, the south of England, the east of Ireland, the north of Scotland. Numerous localities were sampled in Sicily and Cyprus during the study of the family Cladoniaceae in the Mediterranean region (Burgaz et al. 2020), but C. subturgida was not found. Nevertheless we consider it plausible that some populations of $C$. subturgida exist in the northeast of Sicily (Monti Peloritani, Messina province) where the potential vegetation corresponds to oakwoods of Quercus suber. In Cyprus it is also likely for the species to be present in some spots of acid substrate. Corsica presents a large extensión of acid substrates (Reille et al. 1997) and is another region where the species probably grows and should be looked for. In Italy C. subturgida has only been found in Calabria region to date, but the models point out for this country a wider distribution, broadly coincident with the humid, submediterranean, Tyrrhenian zone (Incerti and Nimis 2006). In Calabria, C. subturgida probably restricts itself to a narrow coastal strip, the true location of the Mediterranean vegetation (Nimis 2016). But more populations of this species are to

Table 4 AUC values for the distribution models with selection of variables estimated

\begin{tabular}{ll}
\hline Method & AUC value \\
\hline MAXENT & 0.989 \\
GAM & 0.970 \\
GLMs & 0.948 \\
MARS & 0.960 \\
\hline
\end{tabular}

be expected in the Tuscany and in parts of the Puglia that share the same vegetation type. We are informed of a population of $C$. subturgida extant in the northwest of Algeria (Boudial et al. unpublished). There probably are still more populations in Algeria and Tunisia, very scarcely sampled regions whose lichen flora is poorly known (Seaward 1996; Amrani et al. 2018; Monia et al. 2018). Even in the south of England some populations of $C$. subturgida can be expected in habitats where $C$. firma and $C$. cervicornis have been reported.

It is helpful to keep in mind that the distribution models generated here only included climatic variables, but the soil conditions, key in the distribution of this species, were not included. Cladonia subturgida is restricted to acid pH substrates (Burgaz and Ahti 2009), and many of the areas potentially suitable for the species from a climatic standpoint present a basic $\mathrm{pH}$ (gypsisols or calcisols), therefore it is probable that this model overpredicts $C$. subturgida distribution. For example, a large part of the north of Morocco, a great part of Sicily, some of the selected areas of Cyprus, and some locations of southern England present calcareous substrates (Jones et al. 2010, 2013; Cohen et al. 2012; Soilscape, https:// www.landis.org.uk/soilscapes).

According to our results, the distribution of C. subturgida would be similar to that of $C$. firma, that grows in the southwest of Europe, the north of Africa, the Macaronesia, the west of Asia, occasionally the English Channel islands and southern Britain (Burgaz and Ahti 2009; James 2009; Nimis 2016). In general, both species live together in bare soils, roadside slopes and shrubland clearings in the Iberian Peninsula (Burgaz and Ahti 2009).

Table 5 Relative contribution of each bioclimatic variable to the Maxent model, calculated with jackknife test

\begin{tabular}{ll}
\hline Bioclimatic variables & Relative importance (\%) \\
\hline Precipitation of Warmest Quarter & 25.6 \\
Annual Precipitation & 37.3 \\
Temperature Seasonality & 19.3 \\
Mean Temperature of Driest Quarter & 1.8 \\
Annual Mean Temperature & 9.9 \\
Mean Temperature of Coldest Quarter & 6 \\
\hline
\end{tabular}


Fig. 3 Consensus distribution model for Cladonia subturgida in Europe based on Maxent, GAM, GLM and MARS methods with selection of variables

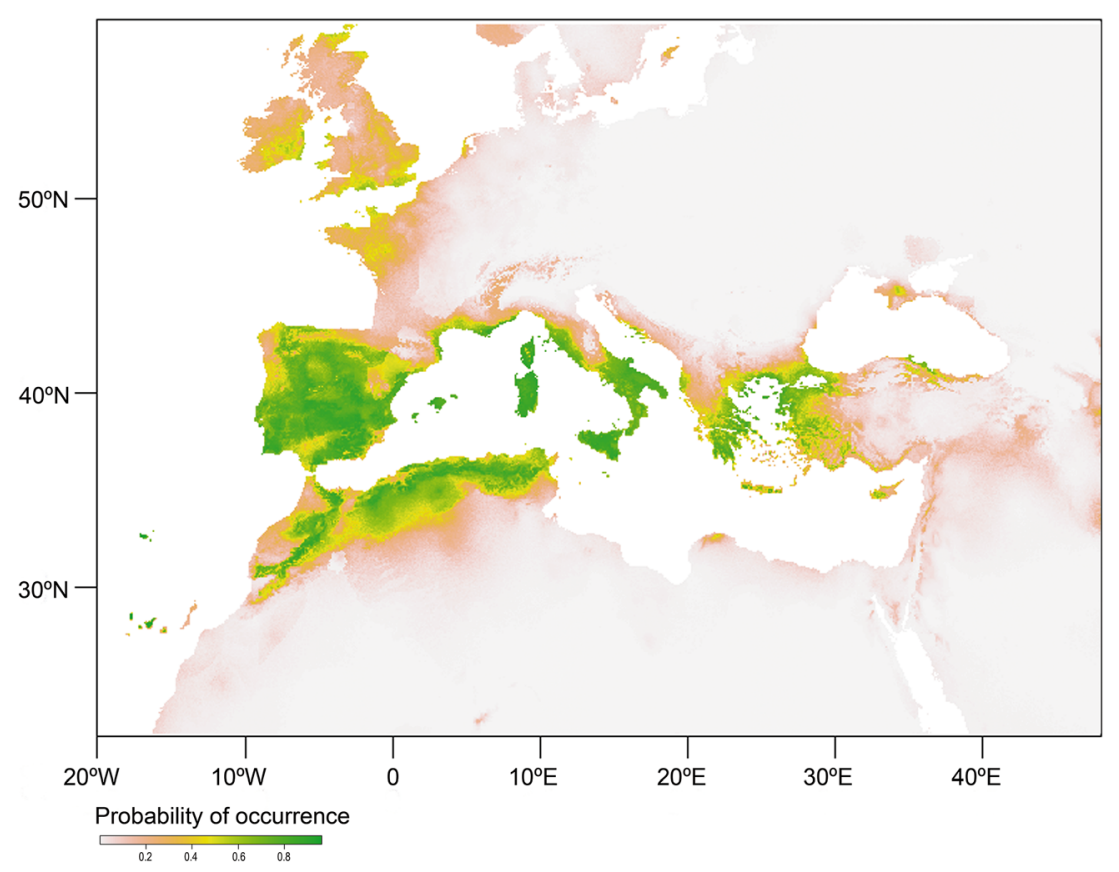

The most relevant climatic variables in the distribution model for C. subturgida are those related to precipitation. Litterski and Ahti (2004) had already pointed out that humidity is the most important limitant climatic factor in the distribution of Cladonia species, in fact more than temperature. Species distribution models have proved that the variables related to precipitation are the key ones to predict the distribution of other Mediterranean species such as Solenospora candidans, S. grisea and S. olivacea subsp. olbiensis (Guttová et al. 2019).

\subsection{Chemical and genetic variation of Cladonia subturgida across its distribution}

As previous studies have proved (Burgaz and Ahti 2009; Pino-Bodas et al. 2012), Cladonia subturgida is a chemically highly variable species. The study of the new specimens gathers together all the six chemotypes found by Pino-Bodas et al. (2012). In accordance with previous findings, the commonest chemotype is the one that contains atranorin and protolichesterinic acid, occasionally accompanied by zeorin. The chemical variation is not homogeneous across the geographical distribution of the species, the Greek populations being the most variable. Specifically five chemotypes have been found in Crete (Table 1).

Genetically C. subturgida is not a very variable species and has a weak geographical structure; there is gene flow among the different regions of the Mediterranean basin. This species reproduces both sexually and asexually but, due to the low frequence of apothecia, it is assumed that asexual reproduction, by means of the dispersion of thallus fragments, is dominant. Therefore, the low genetic variation found was expected, since selection usually affects more directly the genetic variation in asexual species, making most of the loci to be effectively linked (Domaschke et al. 2012). However, a pronounced population structure would be expected due to a lower dispersal capacity of vegetative propagules against spores (Werth 2010; Seymour et al. 2005). But similar results were found in other lichens with dominant asexual reproducction (Werth and Sork 2008), which means that long-distance dispersal of the vegetative propagules is effective. In addition to wind (Muñoz et al. 2004), dispersion through seas (Bailey 1968; Jahns et al. 1976; Søchting and Castello 2012) and birds (Bailey and James 1979; Armstrong 1987; Wedin 1995) have been proposed as dispersal mechanisms in lichens.

Though it is not easy to establish comparisons with other studies (based on different markers and different geographical scales) it is necessary to note that the lack of a geographical structure is a recurent pattern found in several species of the genus Cladonia (Myllys et al. 2003; Yahr et al. 2006; Park et al. 2012; Pino-Bodas et al. 2017). Which means that, in general, Cladonia species have a great dispersal ability and the success of the settlements will be determined by ecological factors.

In some studies about population genetics in the Mediterranean region, some patterns similar to those of Cladonia subturgida have been found, i.e. with scarce genetic variation and populations geographically little structured, for example in Buellia zoharyi (Chiva et al. 2019) and Parmelina carporhizans (Alors et al. 2017). The lack of geographical structure has been attributed to the high dispersal capacity of the species, to the absence of geographical barriers (Alors et al. 2017) and to the fact that the habitats were not affected by glaciations. 


\section{Conclusions}

A knowledge of the species distribution as well as the genetic variation pattern needs to be substantial in order to predict the impact that anthropic disturbances and climatic change will have on them and consequently take appropriate measure for conservation purposes. In many cases, however, this implies a challenge difficult to confront, especially for those species difficult to identify (Allen and McMullin 2019). Therefore, species distribution models can be of great help to identify suitable areas for the species and to efficiently plan the samplings (Hao et al. 2020). Our data, along with the potential distribution models generated in this study, indicate that C. subturgida is a species widely distributed in the Mediterranean region in the Thermomediterranean, Mesomediterranean and Supramediterranean belts.

Acknowledgments This study was funded by the project CGL201341839-P, Ministry of Economy and Competitiveness (MINECO), Spain. R. P-B was supported by Juan de la Cierva-incorporación 201523526, MINECO and a pilot project from Kew foundation.

Open Access This article is licensed under a Creative Commons Attribution 4.0 International License, which permits use, sharing, adaptation, distribution and reproduction in any medium or format, as long as you give appropriate credit to the original author(s) and the source, provide a link to the Creative Commons licence, and indicate if changes were made. The images or other third party material in this article are included in the article's Creative Commons licence, unless indicated otherwise in a credit line to the material. If material is not included in the article's Creative Commons licence and your intended use is not permitted by statutory regulation or exceeds the permitted use, you will need to obtain permission directly from the copyright holder. To view a copy of this licence, visit http://creativecommons.org/licenses/by/4.0/.

\section{References}

Abbott BFM (2009) Checklist of the lichens and lichenicolous fungi of Greece. Bibl Lichenol 103:1-368

Ahti T (2000) Cladoniaceae. Flora Neotrop Monograph 78:1-362

Ahti T, Stenroos S (2013) Cladoniaceae. In: Ahti T, Stenroos S, Moberg R (eds) Nordic lichen Flora, Museum of evolution, vol 5. Uppsala University, Uppsala, pp 1-117

Allen JL, Lendemer JC (2016) Climate change impacts on endemic, highelevation lichens in a biodiversity hotspot. Biodivers Conserv 25(3): 555-568

Allen JL, McMullin RT (2019) Modeling algorithm influence on the success of predicting new populations of rare species: groundtruthing models for the pale-belly frost lichen (Physconia subpallida) in Ontario. Biodivers Conserv 28(7):1853-1862

Alonso FL, Egea JM (1994) Líquenes calcícolas y terrícolas de algunas localidades costeras de Marruecos. Acta Bot Malacit 19:51-61

Alonso FL, Egea JM (1995) Líquenes calcícolas y terrícolas de algunas localidades costeras de Portugal. Nova Acta Científica Compostelana (Bioloxía) 5:39-48
Alors D, Dal Grande F, Cubas P, Crespo A, Schmitt I, Molina MC, Divakar PK (2017) Panmixia and dispersal from the Mediterranean Basin to Macaronesian Islands of a macrolichen species. Sci Rep 7:40879

Amrani S, Seaward MR, Sipman HJM, Feuerer T (2018) Lichenological exploration of Algeria II: checklist of lichenized, lichenicolous and allied fungi. Herzogia 31(2):817-892

Armstrong RA (1987) Dispersal in a population of the lichen Hypogymnia physodes. Environ Exp Bot 27(3):357-363

Bailey RH (1968) Dispersal of lichen soredia in water trickles. Rev Bryol Lichenol 36:314-315

Bailey RH, James PW (1979) Birds and the dispersal of lichen propagules. Lichenologist 11(1):105-106

Barreno E (1991) Phytogeography of terricoIous lichens in the Iberian Peninsula and the Canary Islands. Bot Chron 10:199-210

Bolliger J, Bergamini A, Stofer S, Kienast F, Scheidegger C (2007) Predicting the potential spatial distributions of epiphytic lichen species at the landscape scale. Lichenologist 39:279-291

Burgaz AR, Ahti T (1998) Contribution to the study of the genera Cladina and Cladonia in Spain III. Nova Hedwigia 66:549-555

Burgaz AR, Ahti T (2009) Cladoniaceae. Flora Liquenológica Ibérica vol. 4. Sociedad Espanola de Liquenologica, Madrid, p 111

Burgaz AR, Pino-Bodas R (2012) Notes on species of the genus Cladonia from Bosnia-Herzegovina and Croatia. Bot Complut 36:13-18

Burgaz AR, Fontecha-Galán A, Gutiérrez-Larruga B, Rodríguez-Arribas C (2017) The Cladoniaceae and three additional noteworthy lichens from Croatia. Herzogia 30(1):138-151

Burgaz AR, Luna-González S, Gutiérrez-Larruga B, Pino-Bodas R, Lőkös L, Farkas E (2019a) Diversity of Albanian Cladoniaceae. Bot Complut 43:15-40

Burgaz AR, Gutiérrez B, Pino-Bodas R (2019b) Cladoniaceae of Montenegro. Bot Complut 43:109-139

Burgaz AR, Ahti T, Pino-Bodas R (2020) Mediterranean Cladoniaceae. Sociedad Española de Liquenología, Madrid

Chiva S, Garrido-Benavent I, Moya P, Molins A, Barreno E (2019) How did terricolous fungi originate in the Mediterranean region? A case study with a gypsicolous lichenized species. J Biogeogr 46(3):515525

Clement M, Posada DCKA, Crandall KA (2000) TCS: a computer program to estimate gene genealogies. Mol Ecol 9:1657-1659

Cogoni A, Brundu G, Zedda L (2011) Diversity and ecology of terricolous bryophyte and lichen communities in coastal areas of Sardinia (Italy). Nova Hedwigia 92(1-2):159-175

Cohen DR, Rutherford NF, Morisseau E, Zissimos AM (2012) Geochemical patterns in the soils of Cyprus. Sci Total Environ 420:250-262

Domaschke S, Fernandez-Mendoza F, García MA, Martín MP, Printzen C (2012) Low genetic diversity in Antarctic populations of the lichen-forming ascomycete Cetraria aculeata and its photobiont. Polar Res 31:17353

Ellis CJ (2019) Climate change, bioclimatic models and the risk to lichen diversity. Diversity 11(4):54

Ellis CJ, Coppins BJ, Dawson TP, Seaward MRD (2007) Response of British lichens to climate change scenarios: trends and uncertainties in the projected impact for contrasting biogeographic groups. Biol Conserv 140:217-235

Excoffier L, Lischer HE (2000) Arlequin suite ver 3.5: a new series of programs to perform population genetics analyses under Linux and windows. Mol Ecol Resour 10:564-567

Fady-Welterlen B (2005) Is there really more biodiversity in Mediterranean forest ecosystems? Taxon 54(4):905-910

Fielding AH, Bell JF (1997) A review of methods for the assessment of prediction errors in conservation presence/absence models. Environ Conserv 24(1):38-49

Galloway DJ (2008) Lichen biogeography. In: Nash TH III (ed) Lichen Biology. Cambridge University Press, Cambridge, pp 315-335 
Gardes M, Bruns TD (1993) ITS primers with enhanced specificity for Basidiomycetes - application to the identification of mycorrhiza and rust. Mol Ecol 2:113-118

Gheza G, Assini S, Valcuvia Passadore M (2016) Terricolous lichen communities of Corynephorus canescens grasslands of northern Italy. Tuexenia 36:121-142

Gheza G, Nascimbene J, Mayrhofer H, Barcella M, Assini S (2018) Two Cladonia species new to Italy from dry habitats in the Po plain. Herzogia 31(1):293-304

Glavich DA, Geiser LH, Mikulin AG (2005) Rare epiphytic coastal lichen habitats, modeling, and management in the Pacific northwest. Bryologist 108:377-390

Guttová A, Fačkovcová Z, Martellos S, Paoli L, Munzi S, Pittao E, Ongaro S (2019) Ecological specialization of lichen congeners with a strong link to Mediterranean-type climate: a case study of the genus Solenopsora in the Apennine peninsula. Lichenologist 51(1):75-88

Hall TA (1999) BioEdit: a user-friendly biological sequence alignment editor and analysis program for windows 95/98/NT. Nucleic Acids Symp Ser 41:95-98

Hao T, Guillera-Arroita G, May TW, Lahoz-Monfort JJ, Elith J (2020) Using species distribution models for fungi. Fungal Biol Rev 34:74 88. https://doi.org/10.1016/j.fbr.2020.01.002

Haughland DL, Hillman A, Azeria ET (2018) Tackling rarity and sample bias with large-scale biodiversity monitoring: a case study examining the status, distribution and ecology of the lichen Cladonia rei in Alberta, Canada. Lichenologist 50(2):211-230

Hijmans RJ, Cameron SE, Parra JL, Jones PG, Jarvis A (2005) Very high resolution interpolated climate surfaces for global land areas. Int $\mathrm{J}$ Climatol 25(15):1965-1978

Hijmans RJ, Phillips S, Leathwick J, Elith J, Hijmans MRJ (2017) Package 'dismo'. Circles 9(1):1-68

Incerti G, Nimis PL (2006) Biogeographical outline of epiphytic lichens in a Mediterranean area: Calabria (S Italy). Lichenologist 38(4): 355-371

Jahns HM, Tuiz-Dubiel A, Blank L (1976) Hygroskopische Bewegungen der Sorale von Hypogymnia physodes. Herzogia 4:15-23

James PW (2009) Cladonia P. Browne. In: Smith CW, Aptroot A, Coppins BJ, Fletcher A, Gilbert OL, James PW, Wolseley PA (eds) The lichens of Great Britain and Ireland. British Lichen Society, London, pp 309-338

Jones A, Montanarella L, Micheli E, Spaargaren O, Jones RJA (2010) Major soil types of Europe. European Commission Joint Research Centre. Published by the European Union Publications Office, Luxembourg

Jones A, Breuning-Madsen H, Brossard M, Dampha A, Deckers J, Dewitte O, Gallali T, Hallett S, Jones R, Kilasara M, Le Roux P, Micheli E, Montanarella L, Spaargaren O, Thiombiano L, Van Ranst E, Yemefack M, Zougmore R (2013) Soil atlas of Africa. European Commission, Publications Office of the European Union, Luxembourg

Katoh K, Standley DM (2013) MAFFT multiple sequence alignment software version 7: improvements in performance and usability. Mol Biol Evol 30:772-780

Klement O (1969) Zur Flechtenvegetation der Äolischen Inseln. Herzogia $1: 131-143$

Kocakaya M, Gökhan M, Halıcı MG, Ahti T, Kocakaya Z (2018) New or otherwise interesting records of Cladonia species from Turkey. Herzogia 31:327-331

Kukwa M, Kolanowska M (2016) Glacial refugia and the prediction of future habitat coverage of the south American lichen species Ochrolechia austroamericana. Sci Rep 6(1):1-9

Librado P, Rozas J (2009) DnaSP v5: a software for comprehensive analysis of DNA polymorphism data. Bioinformatics 25(11): $1451-1452$
Litterski B, Ahti T (2004) World distribution of selected European Cladonia species. Symb Bot Ups 34(1):205-236

Litterski B, Mayrhofer H (1998) Catalogue of lichenized and lichenicolous fungi of Cyprus. Stud Geobot 16:57-70

Llimona X, Hladún NL (2001) Checklist of the lichens and lichenicolous fungi of the Iberian Peninsula and Balearic Islands. Bocconea 14:5581

Martínez I, Escudero A, Maestre FT, de la Cruz A, Guerrero C, Rubio A (2006) Small-scale patterns of abundance of mosses and lichens forming biological soil crusts in two semi-arid gypsum environments. Aust J Bot 54(4):339-348

Mayrhofer H, Rohrer A, Bilovitz PO (2013) Catalogue of the lichenized and lichenicolous fungi of Macedonia (FYROM). Phyton (Horn, Austria) 53:23-72

Médail F, Quézel P (1999) Biodiversity hotspots in the Mediterranean Basin: setting global conservation priorities. Conserv Biol 13(6): $1510-1513$

Milborrow S, Hastie T, Tibshirani R (2014) Earth: multivariate adaptive regression spline models. R package version 3.2.7 http://CRAN.Rproject.org/package=earth

Monia AA, Rafika B, Tarek H (2018) Lichen diversity in the Edough peninsula, north east of Algeria. Bot Complut 42:9-18

Muñoz J, Felicísimo A, Cabezas F, Burgaz AR, Martínez I (2004) Wind as a long-distance dispersal vehicle in the southern hemisphere. Science 304:1144-1147

Myers N, Mittermeier RA, Mittermeier CG, da Fonseca GAB, Kent J (2000) Biodiversity hotspots for conservation priorities. Nature 403(6772):853-858

Myllys L, Stenroos S, Thell A, Ahti T (2003) Phylogeny of bipolar Cladonia arbuscula and Cladonia mitis (Lecanorales, Euascomycetes). Mol Phylogenet Evol 27(1):58-69

Nimis PL (1996) Towards a checklist of Mediterranean lichens. Bocconea 6:5-17

Nimis PL (2016) The lichens of Italy. A second annotated catalogue. EUT Edizioni Università di Trieste, Trieste

Nimis PL, Martellos S (2004) Keys to the lichens of Italy. Vol. 1: terricolous species. Edizioni Goliardiche, Trieste

Nimis PL, Poelt J (1987) The lichens and lichenicolous fungi of Sardinia (Italy). An annotated list. Studia Geobot 7(1):1-269

Nimis PL, Tretiach M (1995) The lichens of Italy. A phytoclimatic outline. Cryptogam Bot 5:199-208

Oksanen J, Kindt R, Legendre P, O'Hara B, Stevens MHH, Oksanen MJ, Suggests MASS (2007) The vegan: community ecology package. $R$ package, version 1.17-10

Orange A, James PW, White FJ (2001) Microchemical methods for the identification of lichens. British Lichen Society, London

Park CH, Jeong G, Hong SG (2012) Possible multiple introductions of Cladonia borealis to King George Island. Antarct Sci 24(4):359366

Pearson K, Cameron R, McMullin RT (2018) Habitat associations and distribution model for Fuscopannaria leucosticta in Nova Scotia, Canada. Lichenologist 50(4):487-497

Phillips SJ, Anderson RP, Schapire RE (2006) Maximum entropy modeling of species geographic distributions. Ecol Model 190(3-4):231259

Pino-Bodas R, Martín MP, Burgaz AR (2012) Cladonia subturgida and C. iberica (Cladoniaceae) form a single, morphologically and chemically polymorphic species. Mycol Prog 11(1):269-278

Pino-Bodas R, Laakso I, Stenroos S (2017) Genetic variation and factors affecting the genetic structure of the lichenicolous fungus Heterocephalacria bachmannii (Filobasidiales, Basidiomycota). PLoS One 12(12):e0189603

Reille M, Gamisans J, De Beaulieu JL, Andrieu V (1997) The late-glacial at lac de Creno (Corsica, France): a key site in the western Mediterranean basin. New Phytol 135(3):547-559 
Roux C (2012) Liste des lichens et champignons lichénicoles de France. Bull Soc Linn Provence 16:3-220

Roux C (2017) Catalogue des lichens et champignons lichénicoles de France métropolitaine. 2e édition revue et augmentée. Association française de lichénologie, Fontainebleau

Sampaio G (1918) Contribuiçoes para o estudio dos líquenes portugueses. Ann Acad Polytechn Porto 12:24

Schoch CL, Seifert KA, Huhndorf S, Robert V, Spouge JL, Levesque CA, Chen W, Fungal Barcoding Consortium, Fungal Barcoding Consortium Author List, Bolchacova E, Voigt K, Crous PW, Miller AN, Wingfield MJ, Aime MC, An KD, Bai FY, Barreto $\mathrm{RW}$, Begerow D, Bergeron MJ, Blackwell M, Boekhout T, Bogale M, Boonyuen N, Burgaz AR, Buyck B, Cai L, Cai Q, Cardinali G, Chaverri P, Coppins BJ, Crespo A, Cubas P, Cummings C, Damm U, de Beer ZW, de Hoog GS, del-Prado R, Dentinger B, Dieguez-Uribeondo J, Divakar PK, Douglas B, Duenas M, Duong TA, Eberhardt U, Edwards JE, Elshahed MS, Fliegerova K, Furtado M, Garcia MA, Ge ZW, Griffith GW, Griffiths K, Groenewald JZ, Groenewald M, Grube M, Gryzenhout M, Guo LD, Hagen F, Hambleton S, Hamelin RC, Hansen K, Harrold P, Heller G, Herrera C, Hirayama K, Hirooka Y, Ho HM, Hoffmann K, Hofstetter V, Hognabba F, Hollingsworth PM, Hong SB, Hosaka K, Houbraken J, Hughes K, Huhtinen S, Hyde KD, James T, Johnson EM, Johnson JE, Johnston PR, Jones EBG, Kelly LJ, Kirk PM, Knapp DG, Koljalg U, Kovacs GM, Kurtzman CP, Landvik S, Leavitt SD, Liggenstoffer AS, Liimatainen K, Lombard L, Luangsa-ard JJ, Lumbsch HT, Maganti H, Maharachchikumbura SSN, Martin MP, May TW, McTaggart AR, Methven AS, Meyer W, Moncalvo JM, Mongkolsamrit S, Nagy LG, Nilsson RH, Niskanen T, Nyilasi I, Okada G, Okane I, Olariaga I, Otte J, Papp T, Park D, Petkovits T, Pino-Bodas R, Quaedvlieg W, Raja HA, Redecker D, Rintoul TL, Ruibal C, Sarmiento-Ramirez JM, Schmitt I, Schussler A, Shearer C, Sotome K, Stefani FOP, Stenroos S, Stielow B, Stockinger H, Suetrong S, Suh SO, Sung GH, Suzuki M, Tanaka K, Tedersoo L, Telleria MT, Tretter E, Untereiner WA, Urbina H, Vagvolgyi C, Vialle A, Vu TD, Walther G, Wang QM, Wang Y, Weir BS, Weiss M, White MM, Xu J, Yahr R, Yang ZL, Yurkov A, Zamora JC, Zhang N, Zhuang WY, Schindel D (2012) Nuclear ribosomal internal transcribed spacer (ITS) region as a universal DNA barcode marker for fungi. PNAS 109(16):6241-6246

Seaward MRD (1996) Checklist of Tunisian lichens. Bocconea 6:115148

Seymour FA, Crittenden PD, Dickinson MJ, Paoletti M, Montiel D, Cho L, Dyer PS (2005) Breeding systems in the lichen-forming fungal genus Cladonia. Fungal Genet Biol 42(6):554-563
Søchting U, Castello M (2012) The polar lichens Caloplaca darbishirei and $C$. soropelta highlight the direction of bipolar migration. Polar Biol 35(8):1143-1149

Stamatakis A, Ludwig T, Meier H (2005) RAxML-III: a fast program for maximum likelihood-based inference of large phylogenetic trees. Bioinformatics 21(4):456-463

Stenroos S, Pino-Bodas R, Hyvönen J, Lumbsch HT, Ahti T (2019) Phylogeny of the family Cladoniaceae (Lecanoromycetes, Ascomycota) based on sequences of multiple loci. Cladistics 35(4):351-384

Talavera G, Castresana J (2007) improvement of phylogenies after removing divergent and ambiguously aligned blocks from protein sequence alignments. Syst Biol 56:564-577

Thompson JD (2005) Plant evolution in the Mediterranean. Oxford University Press, Oxford, p 296

Wedin M (1995) The lichen family Sphaerophoraceae (Caliciales, Ascomycotina) in temperate areas of the southern hemisphere. Symb Bot Upsal 31:1-102

Werth S (2010) Population genetics of lichen-forming fungi - a review. Lichenologist 42(5):499-519

Werth S, Sork VL (2008) Local genetic structure in a north American epiphytic lichen, Ramalina menziesii (Ramalinaceae). Am J Bot 95(5):568-576

White FJ, James PW (1985) A new guide to microchemical techniques for the identification of lichen substances. Br Lichen Soc Bull 75:141

White TJ, Bruns T, Lee S, Taylor J (1990) Amplification and direct sequencing of fungal ribosomal RNA genes for phylogenetics. In: Innis MA, Gelfand DH, Sninsky JJ, White TJ (eds) PCR protocols: a guide to methods and applications. Academic Press, San Diego, pp 315-322

Wiersma YF, Skinner R (2011) Predictive distribution model for the boreal felt lichen Erioderma pedicellatum in Newfoundland, Canada. Endanger Species Res 15:115-127

Wood S (2012) Mgcv: mixed GAM computation vehicle with GCV/AIC/ REML smoothness estimation

Yahr R, Vilgalys R, DePriest PT (2006) Geographic variation in algal partners of Cladonia subtenuis (Cladoniaceae) highlights the dynamic nature of a lichen symbiosis. New Phytol 171(4):847-860

Publisher's note Springer Nature remains neutral with regard to jurisdictional claims in published maps and institutional affiliations. 